\title{
Between Non-human and Individual Agents: The Attribution of Agency in Chapters on the Cold War in Flemish History Textbooks
}

\section{Karel Van Nieuwenhuyse}

'Yes we can!' was the chant American presidential candidate Barack Obama used during his campaign of 2008, referring to the power of ordinary people to shape society and determine its direction. These words indicated that ordinary citizens are not just the passive playthings of anonymous power structures or higher powers within the Washington bureaucracy. In short, the chant, which has since become legendary, revealed the agency of ordinary people. Agency can be defined as 'the ability to act on decisions in order to bring about desired goals (whether those involve changing aspects of society or conserving them)' (Barton 2012, 132). The concept of agency is very important when thinking about society, be it in the present or past. Key questions historians ask about past societies are: Who has agency in society? Who co-determines the course of society? Who can make a difference in society? Who has the ability to bring about change over time? How do social, institutional and

\footnotetext{
K. Van Nieuwenhuyse $(\bowtie)$

University of Leuven, Research Unit of History, Leuven, Belgium e-mail: karel.vannieuwenhuyse@kuleuven.be 
cultural structures interact with the agency of individuals and/or groups? Over the past two centuries, historians have come up with different answers to these pressing questions (Seixas 2012).

Some historians have located agency especially in the hands of 'great men'. Thomas Carlyle's lectures On Heroes, Hero-Worship and the Heroic in History (1841) provide us with classic examples of this tendency. Other historians, at least in the positivist tradition, have searched for historical patterns and pointed to non-human actors, structures and comprehensive systems as agents of change or continuity, such as nations, international alliances, religious denominations or ideological systems, or they have focussed on ordinary people and/or on groups previously considered relatively powerless. Some scholars have also cast doubt on the notion of agency. The philosopher Charles Taylor (1989), for instance, relates agency to the era of modernity and the rise of individualism: In his opinion, agency cannot be a transhistorical category but rather constitutes a particular analytical lens for a particular time (modernity). Poststructuralists question the concept of agency altogether, since they consider individuals to be 'constructs mediated by and/or grounded on a social discourse beyond (way beyond) individual control' (Alcoff 1994, 103).

A pertinent and interesting critique of historians who attribute agency to nations and point to agents like 'the United States', 'the Germans' or 'the Russians' has been formulated by Tara Zahra, who writes about transnational and comparative approaches to the history of modern (Central and Eastern) Europe (2010). Zahra opposes the automatic assignment of membership within a national community and reproaches many scholars for not questioning the resonance of nationalist claims and 'imagined communities'. In this respect, she proposes the concept of 'national indifference', referring to (groups of) people expressing a complete indifference towards (belonging to) the nation. She argues:

Even as historians assert that national groups are imagined communities, they have continued to write the history of Eastern Europe in particular with national groups in starring roles, analysing relations between 'the Czechs', 'the Germans', 'the Poles', 'the Slovenes', as though these collectives were self-evident entities. [...] It may be time, in short, to move beyond imagined communities and to consider the history of individuals who stood outside or on the margins of those communities. (Zahra 2010,97) 
Zahra emphasises the danger of using terms like 'the Americans', terms which suggest that individuals have to belong to groups and that national groups in particular are coherent social agents, opposing the homogenisation of national groups and the erasure of individual agency.

In history education, questions about and reflections on agency are also very important, not only for the students' understanding of (the course of) history, but also because of their pedagogical implications: Scholars are convinced that history education can aid pupils in developing active citizenship because it fosters agency and encourages students to see that the present is not merely determined by the past, but, on the contrary, that change and alternatives are possible, rendering civic engagement worthwhile (Harris 2011; Wilschut 2012; Wilschut et al. 2013). In this respect, however, Peck, Poyntz and Seixas argue that the focus of agency should actually be on ordinary people, so students can understand that if ordinary people participated actively in making the world in the past, then too, ordinary people in the present have an important potential for effecting historical change' $(2011,256)$. Barton agrees with this line of reasoning (2012). He argues that in order to be better prepared to think about their own role in present and future society, students need exposure to a wide range of historical actors, much wider than has traditionally been found in the school subject of history. At the same time, students need to consider the societal factors that enabled or constrained individual and group actions, as well as the diversity of perspectives and behaviours of people in the past. In line with Zahra's argument (2010), another reason to pay attention to a wide range of historical actors in history education is that this can help students consider and build their own identities. If agency is mostly attributed to nations and national groups, it seems as if a national identity is inescapable, as if students themselves do not have the agency or liberty to construct and define their own identities.

The attribution of agency also relates to the specific historical representation of the Cold War that history textbooks pass on to young people. This determines which groups are considered the main protagonists and which are rather portrayed as passive participants who do not play active roles in the conflict. In this respect, it is always important to examine how the role and agency of one's own country is represented, as well as the extent to which this agency is portrayed in a positive way; these aspects can be connected to the identity-building aims of history education. 
The concept of agency in history education, and specifically how it is approached in textbooks and by teachers in their daily classroom practice, has not been examined thoroughly (Seixas 2012). Research into how history is approached in secondary schools, according to the demands of the curriculum, and into the textbooks used shows that a 'social science' vision of history as a discipline often prevails: Textbooks pay particular attention to non-human actors, large social processes and structures rather than to individuals and ordinary people (Erdmann and Hasberg 2011). This seems to indicate that structural entities possess greater capacity for agency than any individual does. As a result, students often attribute (non-human) agency to societal institutions (nations, international alliances and religious denominations) or ideas and movements (such as communism, capitalism and nationalism), assigning them human characteristics (Clark 2013; Ibid. 2014; Ibid. et al. 2011). Students consequently do not fully understand the role of agency in history; nor do they construct a balanced account of the relationship between these structural forces and the actors in historical events or fully grasp the role individuals and ordinary people can play in society.

This chapter focusses on the concept of agency as taught in history lessons in secondary schools in Flanders, whilst analysing chapters about the Cold War - meaning the state of political and military tension after the Second World War between the Soviet Union and its satellite states (the Eastern bloc) and the United States and its allies (the Western bloc) - in four history textbooks. Questions guiding my research and analysis are as follows: (1) To whom is agency ascribed and who remains a passive participant, i.e. is agency attributed especially to structures, institutions, nations, elite persons and/or ordinary men and women? Are the textbooks' 'own' country and population, Belgium and Belgians, attributed agency? And in attributing agency, do the textbook authors reflect on the concept of agency? (2) Who is held responsible for the Cold War? Whose responsibility is amplified and whose is mitigated? In this respect, with which historiographical school do the authors of each of these textbooks align themselves? (3) Do the textbooks pass moral judgment on agents and/or actions taken during the Cold War? Whose actions are constructed as being reasonable or necessary? What attitudes do the authors of these 
textbooks adopt towards the Western and Eastern blocs? It is difficult, perhaps impossible, to discern moral judgment; often the line between historical description and moral judgment is rather thin. Is describing Stalin as a dictator, for instance, depicting his leadership accurately or casting him in a negative light? The same question applies to the example of American 'interference' in Latin America, which will be addressed in more detail in the following.

The analysis examines the four textbooks from a comparative perspective, with a particular interest in the level of coherence within each textbook. The chapter first sketches the research context and methodology before presenting the findings.

\section{Research Context and Methodology}

In 1989, power in regards to education in Belgium was formally transferred from the national, federal level to the three Belgian 'communities': the Dutch (Flemish), French and (very small) German communities. In 1990, a new secondary-school curriculum was introduced in Flanders, the northern, Dutch-speaking part of Belgium. This curriculum is still used. The Flemish government set final objectives or standards for teaching history, delineating the minimum attainment targets that history students should achieve. In defining these standards, a deliberate choice was made not to present an extensive enumeration of the historical knowledge that students would be required to learn (Flemish Ministry of Education and Training, 2000a; ibid. 2000b). The history curriculum primarily aims to develop critical thinking skills and attitudes, namely historical consciousness. Flemish history education is characterised by a very structural approach to the past, based on the social sciences (Wils 2009): It searches for large, underlying patterns in the past. It is no coincidence that the standards, for instance, (implicitly) refer to Fernand Braudel's ideas about history. They address what Braudel calls 'mediumterm' or cyclical history, focussing on empires, civilisations, the economy, and social groupings (1949). This approach to studying the past results in large, abstract narratives in which there is little room for the individual's own narrative, thoughts and actions. 
An important goal of history education is the construction of a historical frame of reference in students' minds. The main frame of reference in Flemish history education is Western (especially Western European), although students are explicitly encouraged to frame historical phenomena in a broader, worldwide context. The standards require, for instance, that in each of the three stages of teaching history at secondary level, the history of at least one non-Western society is addressed. Nevertheless, the history curriculum remains oriented towards the West, suggesting that this is the most important focus of history and emphasising Europe and the Western World's slow but steady rise towards human rights, democracy and freedom (Van Nieuwenhuyse and Wils 2015).

The ways in which history education is given shape by actual classroom practice, however, is not only determined or influenced by standards; textbooks also play a role. It is important to note that the government does not regulate the production and distribution of textbooks in Flanders. Therefore, publishers have great freedom when it comes to designing their history textbooks, although they claim to base them on the curricular standards. Indeed, similar to the standards, the underlying narrative in Flemish history textbooks is a Western-oriented, liberal narrative of progress, as Bert Vanhulle has shown (2005; 2009).

This research examines the chapters on Cold War history in all Flemish history textbooks for general secondary school education for the twelfth grade, since this is when students study the post-war period. More specifically, my analysis looks at the textbooks Historia 6 (De Deygere et al. 2009), Storia 6 (Bekers et al. 2009), Passages: Na de Tweede Wereldoorlog (Draye et al. 2010), henceforth: Passages, and Pionier 6 (Smeulders et al. 2014).Given the relatively small market for secondary school history textbooks, the profit and investment margins for these works are generally not very broad. This means that the authors of most textbooks are not professional (academic) historians; instead, textbooks are usually written by history teachers who take on the task on top of their teaching duties. Another consequence is that new textbooks often build on preceding versions and seldom start with a clean slate. This applies to Historia 6 and Storia 6 , two textbooks written by secondary school history teachers. Passages and Pionier 6 are both entirely new. Whilst Pionier is also written by secondary school history teachers, Passages is the only history 
textbook in Flanders written and supervised by academic cultural historians; indeed, the explicit goal of the editing team was to contextualise the textbook account within academic historiography.

This study applied both a qualitative narrative content analysis and a discourse analysis to the textbooks. The narrative content analysis entailed examining the representation of the Cold War as embedded in the textbook narrative as a whole, because only as part of a whole does a specific section take on significance (Vanhulle, 2009). In order to analyse the concept of agency in each of the textbook chapters on the Cold War, I designed a coding scheme of categories of (human and non-human) agents, starting from a grounded theory approach, which relied on close reading and data analysis rather than theoretical frameworks. A distinction was made between actors who were attributed agency and entities assigned to a more passive role. I chose 'utterances' as the unit of analysis, defined as 'a phrase or a sentence that included a mention of a historical agent, or a pronoun referring to one' (Peck et al. 2011, 262). One utterance could consist of consecutive sentences if they were all about the same historical agent or entity. Searching for specific representations of the main agents and actors of the Cold War (and their presumed responsibilities), the discourse analysis focussed on the verbs used to describe the actions of both Soviets and Americans, as well as on keywords used about them.

\section{Research Results}

\section{General (Descriptive) Findings}

The Cold War is addressed in history textbooks for the twelfth grade, which deal with the post-war period. This means that, according to the textbook authors, the Cold War only began after the end of the Second World War. Historians, however, disagree on when the Cold War commenced. While many refer to the years between 1945 and 1947 as the start, others, such as the French historian André Fontaine or the Belgian historian Yvan Vanden Berghe, refer to points as early as the Russian Revolution of 1917 (2006; 2008). The textbooks Historia and Storia seem to implicitly reference this historiographical debate, since they both 
begin paragraphs on 'The Origin of the Cold War' with reference to 1917. At the same time, in the general introductions, the authors of both textbooks state that after the Second World War, relations between the United States and the Soviet Union worsened, resulting in an ideological battle and the beginning of the Cold War.

The four twelfth-grade textbooks under study arrange their content differently. While Historia and Pionier start from a chronological division into two main periods - 1945 to 1989 or 1991 (the period of 'the Cold War', with capitals) and 1989 and 1991 to present - Storia and Passages apply a thematic division. The former uses a rather straightforward, concrete, content-based division, starting with a chapter on the Cold War and subsequently proceeding to other themes such as European history, Belgian history, evolutions in science and technology, and different world views. The latter identifies five more abstract themes: 'war', 'labour', 'people and nation', 'nature', 'the individual'. All the textbooks start with political issues, then proceed to economics and end with socio-cultural issues. Political and economic themes occupy the lion's share of the textbook content: 91 per cent of all content in Historia and Pionier, 74 per cent in Storia and 60 per cent in Passages. Socio-cultural themes are thus addressed in much less detail, with almost no attention paid to the daily lives of ordinary people. These findings confirm what previous studies have shown about current, structurally informed approaches to the past, with influence from the social sciences, in Flemish history education, focusing on large structures rather than individuals. The international (especially Western) orientation of these textbooks is reflected when we compare the number of pages devoted to national and international issues. In each, just 13 per cent to 23 per cent of the whole is reserved for national, Belgian history. While Historia and Pionier focus especially on the East-West gap, Passages and Storia pay equal attention to both the East-West and the North-South divide. Differences among the textbooks also arise regarding the weight given to the two main time periods in the post-war era, namely 1945 to 1989 or 1991 and 1989 or 1991 to the present. While Storia and Passages (85 per cent of all content) and, to a lesser extent, Pionier (68 per cent of all content) mainly focus on the Cold War period, Historia devotes an equal amount of attention to both time periods. 
Table 8.1 Overview of the Main Chronological, Geographical and Contentrelated Points of Focus in Four Textbooks

\begin{tabular}{|c|c|c|c|c|c|}
\hline & $\begin{array}{l}\text { Total } \\
\text { number of } \\
\text { pages in the } \\
\text { twelfth- } \\
\text { grade } \\
\text { textbook (+ } \\
\text { format) }\end{array}$ & $\begin{array}{l}\text { Pages devoted } \\
\text { to the Cold } \\
\text { War period } \\
(1945-1989 / 91) \\
\text { vs. } \\
1989 / 91- \\
\text { present }\end{array}$ & $\begin{array}{l}\text { Pages } \\
\text { devoted to } \\
\text { international } \\
\text { vs. national } \\
\text { affairs (in } \\
\text { percentage) }\end{array}$ & $\begin{array}{l}\text { Pages } \\
\text { devoted to } \\
\text { East-West } \\
\text { gap vs. } \\
\text { North-South } \\
\text { gap (in } \\
\text { percentage) }\end{array}$ & $\begin{array}{l}\text { Pages } \\
\text { devoted to } \\
\text { politics/ } \\
\text { economy vs. } \\
\text { culture/ } \\
\text { everyday } \\
\text { life (in } \\
\text { percentage) }\end{array}$ \\
\hline Historia & 205 рр. (A4) & $51 \%$ vs. $49 \%$ & $87 \%$ vs. $13 \%$ & $71 \%$ vs. $29 \%$ & $91 \%$ vs. $9 \%$ \\
\hline Passages & 140 рp. (A4) & $89 \%$ vs. $11 \%$ & $86 \%$ vs. $14 \%$ & $42 \%$ vs. $48 \%$ & $60 \%$ vs. $40 \%$ \\
\hline Pionier & 345 рр. (B5) & $68 \%$ vs. $32 \%$ & $77 \%$ vs. $23 \%$ & $75 \%$ vs. $25 \%$ & $91 \%$ vs. $9 \%$ \\
\hline Storia & 173 рр. (A4) & $85 \%$ vs. $15 \%$ & $82 \%$ vs. $18 \%$ & $48 \%$ vs. $52 \%$ & $74 \%$ vs. $26 \%$ \\
\hline
\end{tabular}

The Cold War itself is also addressed on a different scale in the four textbooks, as the table shows. In general, the Cold War does not receive the most attention. While it is considered an important issue, it is nevertheless merely one among many others, such as the European unification process, the federalisation of Belgium, decolonisation, the Israeli-Palestinian conflict, environmental problems, and cultural changes in the West after 1945. All four textbooks deal with the Cold War in a purely international context. The ramifications of the Cold War in Belgium are not addressed. A telling example in this respect is the historical source included in the textbook Storia, which is an excerpt from the Belgian communist newspaper De Rode Vaan, from 4 July 1948, with the following headline: 'Spaak Signs the Bilateral Agreement that Surrenders Belgium to the Americans' (40). The article refers to the agreement that Paul-Henri Spaak, the Belgian minister for foreign affairs, signed regarding the conditions for Belgium to receive Marshall aid. The only question accompanying the source is: 'Has the Marshall Plan been received in a positive way everywhere in Europe? Discuss the reasons for your answer'. The question shows that the source has not been included to highlight the impact of the Cold War on specifically Belgium, such as the political tensions it caused between different parties. Instead, the focus is on Western Europe, illustrating a very Western and (Western) European orientation of history education in Flanders. This approach to the past is also reflected in the chapters on the Cold War: The accounts focus especially on political and economic aspects, placing far less to (almost) no emphasis on culture, especially everyday life. 
An exception in this respect is the textbook Passages - not coincidentally written by academic cultural historians. The authors of Passages, and to a lesser extent those of Pionier, do address the influence of the Cold War on ordinary people, by including testimonies about how their lives were affected, for instance, or photographs of a nuclear attack drill in an American school in 1951. Passages also argues that the Cold War was fought not only on a political and economic level but also on a cultural level. Its authors elaborate, for instance, on how the Cold War affected sports and space policies.

Despite some differences, the main political and economic account of the Cold War is largely the same in all four textbooks. For the period from the 1940s to the 1950s, all textbooks address the origins of the Cold War, the American containment policy (related to the Truman Doctrine of 1947 and the Marshall Plan of 1947 to 1952), the establishment of Comecon (1949), the division of Europe and the Berlin Blockade (1948-49), the Korean War (1950-53), the establishment of the military alliances NATO (1949) and Warsaw Pact (1955), the temporary détente and co-existence policy of the 1950s, as well as the 1950s uprisings in the Eastern Bloc, at least in the GDR in 1953 and Hungary in 1956. The Polish uprising of 1956 is mentioned only in Historia and Pionier. Only Pionier mentions McCarthy and his 'witch hunt' in the United States in the early 1950s. The existence of Gulags in the Soviet Union is not mentioned in any of these four twelfth-grade textbooks. This is striking because all four corresponding textbooks for the eleventh grade, which cover material from around 1750 to 1945 and thus also the inter-war period, do include the Soviet Gulags.

Table 8.2 The Treatment of the Cold War in the Four Textbooks

\begin{tabular}{|c|c|c|c|c|c|}
\hline & $\begin{array}{l}\text { Total } \\
\text { number of } \\
\text { pages in the } \\
\text { twelfth- } \\
\text { grade } \\
\text { textbook (+ } \\
\text { format) }\end{array}$ & $\begin{array}{l}\text { Pages } \\
\text { devoted } \\
\text { to the } \\
\text { cold war }\end{array}$ & $\begin{array}{l}\text { Pages } \\
\text { devoted to } \\
\text { the cold war } \\
\text { (in } \\
\text { percentage) }\end{array}$ & $\begin{array}{l}\text { Pages dealing } \\
\text { with the cold } \\
\text { war, devoted to } \\
\text { international vs. } \\
\text { national affairs }\end{array}$ & $\begin{array}{l}\text { Pages } \\
\text { dealing with } \\
\text { the cold war, } \\
\text { devoted to } \\
\text { politics/ } \\
\text { economy vs. } \\
\text { culture/ } \\
\text { everyday life }\end{array}$ \\
\hline Historia & 205 рр. (A4) & 14 pp. & $7 \%$ & $100 \%$ vs. $0 \%$ & $100 \%$ vs. $0 \%$ \\
\hline Passages & 140 рр. (A4) & 14 pp. & $10 \%$ & $100 \%$ vs. $0 \%$ & $64 \%$ vs. $36 \%$ \\
\hline Pionier & 345 рр. (B5) & 47 рp. & $14 \%$ & $100 \%$ vs. $0 \%$ & $87 \%$ vs. $13 \%$ \\
\hline Storia & 173 рр. (A4) & 17 pp. & $10 \%$ & $100 \%$ vs. $0 \%$ & $100 \%$ vs. $0 \%$ \\
\hline
\end{tabular}


All textbooks, however, address the building of the Berlin Wall (1961), the Sino-Soviet split (1961), the Cuban Missile Crisis (1962), the thaw under Khrushchev, the escalation of the Vietnam War (1965 to 1973), the uprisings in the Eastern Bloc (1960s to 1970s), especially in Czechoslovakia (1968), American interference in Latin America, Asia and sub-Saharan Africa (1950s to 1980s), the Brezhnev Doctrine, the Ostpolitik of Willy Brandt and the SALT (1971 to 1972) and the Helsinki agreements (1975). Again, small differences emerge. Historia, for instance, does not mention that the removal of nuclear missiles from Turkey by the United States and NATO was part of the deal between Khrushchev and Kennedy in order for the latter to secure the withdrawal of Soviet nuclear missiles from Cuba. Passages is the only textbook to mention that the American nuclear missiles in Italy were also included in this deal. A marked difference arises from Storia's account of American interference in different parts of the world from the 1950s onwards. While the three other textbooks clearly address this topic and provide one or more examples (from Iran, El Salvador, Chile or Guatemala), Storia hardly mentions American interference. In their accounts of the Cold War during the 1980s, all textbooks touch on the renewed confrontation policy, the arms race and the MAD doctrine, new uprisings (especially in Poland in 1980), the war in Afghanistan, the new détente (with Gorbachev), the fall of the Berlin Wall, the end of communism in Eastern Europe and the implosion of the Soviet Union.

Two other important phenomena and developments from the Cold War period (1945 or 1947 to 1989 or 1991), the European unification process and the expansion of the welfare state, are dealt with in all textbooks in a specific and separate (sub)chapter. The Israeli-Palestinian conflict and other developments in the Middle East are only partly framed within the Cold War context; they are also connected to global democracy, emancipation and decolonisation and, therefore, to the NorthSouth divide as well. Decolonisation itself is addressed in a separate chapter, only tangentially connected to the Cold War context. The accounts on decolonisation in all four textbooks are rather general; they don't elaborate on one case in depth although some specific attention is paid to the decolonisation of India, the Congo, the Dutch East Indies and Ethiopia. 


\section{The Attribution of Agency throughout the Cold War}

Three categories of agency and agents can be discerned in the four textbooks examined. In the first and most common category, non-human agency prevails. The textbook authors situate agency in the Cold War first and foremost in the hands of the United States and the Soviet Union rather than to people, factions, groups or institutions within each of the countries (such as secret intelligence agencies such as the KGB or CIA, the military-industrial complex or hawks in government circles). Sometimes the terms 'United States' and 'Soviet Union' seem interchangeable with 'capitalism' and 'communism', respectively, also non-human actors. Historia, for instance, states: 'In the opinion of the United States, communism on the march had to be contained' (25).

The second category does include human agency, here attributed, if much less frequently, to individuals from both camps in the Cold War. Above all, the agents are 'great', white men, notably the leaders of the United States and the Soviet Union, such as Truman, Eisenhower, Kennedy, Reagan, Stalin, Khrushchev and Gorbachev. Passages and Storia differ to a certain extent, because they also attribute agency to other individuals, either to the leaders of other countries (such as Tito, Castro or Thatcher) or opposition leaders (such as Lech Walesa). The roles of ordinary people are not mentioned. In this second category, there seems to be little difference in the amount of emphasis placed on human agency within both blocs.

Three of the four textbooks also attribute agency beyond the two superpowers and 'great men'. With the exception of Historia, all mention certain countries and groups as active agents. They mention countries belonging to one of the two camps and 'Third World' countries, as well as groups such as labourers, intellectuals, students (sometimes mentioned together, their actions characterised as protest movements), public opinion, the people, the army or political parties. Although these are mostly mentioned as passive entities, they are nevertheless attributed some agency in the context of certain events, especially towards the end of the Cold War. 'The people', for instance, along with the protest movements of students and labourers, are ascribed an important role in the fall of communism in Eastern Europe at the end of the 1980s and in the dissolution of the Soviet Union in 1991. In some cases, the stress is placed on 'multi-staged' agency: Only when 
approved by a superpower could a country or group start to roll out a certain policy. Passages, for example, writes that the vassal states of Eastern Europe dealt with their internal affairs themselves from the mid-1980s onwards once this had been approved by Gorbachev. Storia mentions that the communist political parties in Eastern Europe applied a specific strategy in order to seize power, but were nevertheless subject to the orders of the Soviet Union. Again, the authors of the four textbooks vary just as much for the Eastern as for the Western bloc in this third category.

In view of these three categories of agents and agency, to what extent do the twelfth-grade history textbooks represent the superpowers as homogeneous entities, and how much weight do they give to alternative voices? While Historia does not pay much attention to opposition within each of the power blocs, Passages, Pionier and Storia do. Passages states: 'Both power blocs were less homogeneous than they seemed at first sight' (14-15). The textbook explains, for instance, that different opinions existed within each bloc on how to deal with the opponents of the other bloc. When describing the détente after the Cuban Missile Crisis in the early 1960s, Storia states that not everyone in the United States was happy with this new policy (35). Pionier mentions that the people on both sides of the Iron Curtain disliked the new arms race at the beginning of the 1980s and organised several protests (94). Counter-voices, nevertheless, are introduced mostly in the (primary) sources accompanying the learning texts. While Passages presents counter voices within both camps (for instance, a Catholic priest receiving someone's confession at the shipyard of Gdansk or people in New York demonstrating against the arms race in 1961, 15), Pionier solely focusses on counter-voices within the Western camp. Storia, by contrast, does the opposite and offers only alternative voices from the Eastern bloc (46-48).

In examining the agency attributed by the textbook authors, it is important to analyse not only who is attributed agency but also who is not and even to analyse which groups are silenced in their accounts. All four textbooks' accounts of the Cold War are characterised by an abstract approach. The actual ordinary individual is almost completely ignored. In rare exceptions to this rule, he/she can be seen in a visual primary source included in the textbook, either as a passive victim of a proxy war (such as Kim Phuc in the iconic photograph showing the consequences of bombarding a Vietnamese village) or as a protester against the arms race. 
Women are also completely silenced by these textbooks. Only in the learning text of one book, Passages, is one woman mentioned and attributed agency: Margaret Thatcher. Storia mentions the role of Mr and Mrs Ceaușescu in Romania (yet focusses on the husband's role) and Pionier notes the alleged role of $\mathrm{Mr}$ and Mrs Rosenberg in the espionage scandal in the United States in the 1940s and early 1950s. Neither Belgium nor any Belgians are mentioned in any textbook, and thus they are not attributed any agency. When considered in comparison with an international perspective, this might seem surprising; in the Flemish context, however, it reflects established trends. Once again, the textbooks illustrate the very (Western) European orientation of Flemish history education and the absence of attention to the learners' 'own' specific national past.

Textbook authors, furthermore, do not explicitly reflect on the concept of agency in the Cold War. They do not clearly address, for instance, to what extent ordinary people as a group and ordinary individuals were or were not passive playthings in the hands of superpowers. Nor do they instigate explicit reflection about how much agency the countries of a certain camp had vis-à-vis the superpower above them or raise questions about the relations between the people and the upper class or even within the upper class. The concept of agency itself, with all its complexities, remains below the surface of the textbooks' accounts.

\section{Attribution of Agency and Responsibility for the Outbreak (and Continuation) of the Cold War}

Another issue only implicitly touched upon by some of the textbooks is the question of responsibility for the Cold War. Since the 1950s, historians have sharply disagreed in this area. Soviet historiography, under central control, argued that responsibility lay with the West, while in the United States the 'orthodox' school blamed the Soviet Union and its expansion into Eastern Europe. In the 1960s and 1970s, however, revisionist scholars in the West started to challenge the widely accepted 'orthodox' view and considered the United States largely responsible for the Cold War. From the 1970s onwards, a third, post-revisionist school 
emerged among historians, which saw the Cold War as the result of predictable tensions between the United States and the Soviet Union, powers which had been suspicious of one another for many decades (Westad 2000; Vanden Berghe 2008).

First it should be stressed that none of the textbooks analysed here pay much attention to the origins of the Cold War. Each of the Flemish history textbooks spends only one to two paragraphs (half a page to one page) on this subject. Of the four textbooks, only two explicitly deal with the question of responsibility for the outbreak and continuation of the Cold War. While Pionier raises the question of whether or not it is possible to identify a culprit, Storia refers to the existing historiographical debate, stating:

To date, historians still discuss whether or not the fear of communist expansion was justified, and to what extent Western leaders were honest in their statements. The orthodox school passes responsibility for the Cold War entirely onto the Soviet Union and its aggressive post-war politics. The United States, it says, did nothing but react appropriately and rightly. Revisionist historians, by contrast, argue that the Americans demonised the Soviet Union in order to justify their own aggressive and imperialist politics. (34)

Strangely enough, the post-revisionist school is not mentioned.

Throughout their accounts of the origin of the Cold War, all four textbooks take on a post-revisionist stance. They all refer to ideological and geopolitical tensions between the United States and the Soviet Union, as well as to the imperialist aspirations of both superpowers. Its continuation is explained as action and reaction. In other words, both the United States and the Soviet Union are ascribed responsibility, to an equal extent, for the origin (and continuation) of the Cold War. A discourse analysis affirms this finding. For instance, the textbook authors do not use specific verbs or adjectives to implicitly place blame on one of the two actors. Furthermore, the actors responsible for the outbreak of the Cold War are clearly identified as those with non-human agency. The textbooks' authors all identify the United States and the Soviet Union as the responsible parties. Only once in all four textbooks are Truman and Stalin explicitly mentioned. In all other cases, the agents are the two superpowers. 
Only a few other actors are mentioned in relation to the origins and continuation of the Cold War, such as the national communist parties in Eastern Europe who held some power after the Second World War or the Western European countries who asked the Americans to help them work against Soviet expansionism. Nevertheless, according to the textbook authors, a 'multi-staged' agency was at work. First and foremost, responsibility was in the hands of the two superpowers; other actors could only (re)act with Soviet or American permission.

\section{Moral Judgment on Agents and/or Actions during the Cold War}

A further question is whether - and to what extent - any attribution of responsibility by the textbooks goes hand in hand with passing moral judgment on agents and/or actions during the Cold War. This question is not easy to answer. How should we assess statements like 'puppet regimes' to describe Eastern European governments, or the phrase 'witch hunt' to describe McCarthy's persecution of communists, the emphasis on the 'expensive' arms race or the statement (on MAD policies) that 'Both parties still went on developing ever stronger weapons'? On the one hand, these statements seem to impart moral judgments; on the other, however, they could simply be considered descriptive.

When analysing all of the chapters on the Cold War from these textbooks, we can see that the authors approach this conflict, its agents and events, for the most part in a distant, neutral tone without explicit judgement. A discourse analysis reveals no relevant results regarding specific wording. Stalin, for instance, is always mentioned by name only, without loaded adjectives. The textbooks sometimes ascribe him an authoritarian attitude ('Stalin demanded [...]'); however, the same phrasing can also be found in descriptions of Kennedy's actions during the Cuban Missile Crisis. Only in Historia is there one instance of clear moral judgment: In an in-depth study on the nuclear arms race during the Cold War, the author states that, with the disarmament agreements of the 1980s, 'a turn for the better' occurred (107). In Storia, Soviet policies are more readily criticised than American policies. Soviet interference into Eastern 
European countries' internal affairs receives ample attention, for example, while American interference is hardly mentioned. Yet, for the most part, the authors of this textbook maintain a distance from the narrative; they do not show either sympathy or antipathy towards any actors in the Cold War.

Three of the textbooks nevertheless adhere to and lean on a framework of Western values and standards, albeit in a scattered and implicit way. Freedom and respect for human rights are considered important values in these textbooks, and they are portrayed as lacking in the communist bloc according to Historia, Pionier and Storia. Historia states that the GDR was forced to become a Soviet ally, while the FRG chose Westbildung. The right to self-determination and freedom of speech and religion is presented as hugely important in Storia. Pionier elaborates on Pope John XXIII's plea, in his encyclical Pacem in Terris from 1963, which calls for greater respect for human rights, freedom of religion, and dialogue. Consequently, both Soviet and American policies during that period are critically judged based on these (presumably) characteristic Western values. The judgment falls in favour of American policy, although Pionier also critically comments on it. Western values serve as the standard by which to judge different societies. Only Passages avoids a biased perspective altogether.

\section{Conclusion and Discussion}

Taking a comparative perspective, I analysed four Flemish twelfth-grade history textbooks in order to examine which groups or people are ascribed agency and responsibility for either causing or continuing the Cold War, as well as to understand to what extent the textbooks pass moral judgment. The textbooks often attribute agency to three different categories of people or entities: (1) The first and most prominent category concerned non-human agency situated in the hands of the United States and the Soviet Union, (2) the second category consisted of individuals, (3) a rather small third category consisted of certain countries, groups and 'the people' as active agents. In Historia, this third category received hardly any attention. The agency of ordinary people, women and Belgium itself 
were also mostly overlooked in all four textbooks. With the exception of Historia, all the textbooks recognised that both power blocs were nonhomogeneous entities and that counter voices existed on both sides. Responsibility for the Cold War was unanimously dealt with in a postrevisionist manner, with the focus on ideological and geopolitical tensions between the United States and the Soviet Union and their imperialist aspirations. The analysis found that explicit moral judgment did not appear in the textbook accounts, but three of the four works nevertheless adhered to a framework of Western values and standards. Only Passages consistently maintained its distance from this framework.

Despite the differences between these textbooks, an important similarity emerged in terms of their approach to (agency in) the Cold War, which can be characterised as structural and informed by the social sciences. How should this attribution of agency be judged in light of the importance history education scholars ascribe to the representation of agency in (1) fostering students' complex understanding of history, (2) encouraging young people to take up societal and civic commitment and (3) contributing to young people's identity building?

Explaining past events and historical change or continuity with the necessary complexity is a very difficult matter. Analysing agency on different structural, collective and individual levels, however, allows us to have a deeper and more nuanced historical understanding of (the roles of various agents in) past events and developments. To a certain extent, the textbook authors discussed here rise to the challenge posed by such complexity. While they attribute agency to states or to 'great men', they generally pay little attention to the role of other agents. Furthermore, a reflection on the concept of agency itself is absent from the texts. This is a missed opportunity to guide students to reflect on the agents of change in history, as well as the balance between structures, collectives and individuals in creating historical change.

The authors of these four textbooks certainly illustrate the significance and effectiveness of collective action. According to them, it led to the fall of communism in Poland (the role of Solidarnosc in particular), the fall of the Berlin Wall and the fall of communism in general in Eastern Europe. The textbook authors also clearly show that, while collective action does not immediately produce change, it can yield results in the longer term. The elision of the 
importance of individual agency could have an impact on a young person's understanding of how this, too, could lead to historical change.

The emphasis on non-human agents like 'the Soviet Union' or 'the United States' in these textbooks might give students the idea, as Zahra points out, that a national identity is inescapable and they do not have the agency or liberty to construct and define their own identities (2010). An important suggestion in this respect, referring to Rogers Brubaker $(2004,12)$, is to analyse 'groupness' as an 'event' rather than analysing 'nations' or 'states' as historical actors (Zahra 2010, 97). This alerts students to the possibility that 'groupness' may not occur and reveals that national groups are never completely homogeneous, provoking reflections on agency on the structural, group and individual level.

Homogenisation gives rise to another problem, also related to identity building. In the four textbooks, the different blocs involved in the Cold War are mainly represented in a homogeneous way, even though some attention is paid to counter voices. Such a representation, combined with an implicit adherence to Western values and standards, carries certain risks. An 'us-versus-them' contrast can emerge between 'the West' and 'the Rest', with accompanying feelings of Western superiority. Western values and standards are judged positively and represented as being better than those of others, as previous research among Flemish students suggests (Van Nieuwenhuyse and Wils 2015). Furthermore, psychological research (in particular research into social identity theory) shows that homogenising the 'in-group' goes hand in hand with enlarging differences vis-à-vis 'out-groups', exaggerating the positive characteristics of the 'in-group' and stressing the weaknesses or shortcomings of the 'outgroup' (Ford and Tonander 1998), encouraging exclusion.

It would thus be beneficial to combine the current approach (abstract, structural, with an emphasis on theory from the social sciences), which leads to a macro-historical perspective and an emphasis on non-human agents (which is certainly still valuable), with a micro-perspective focussing on the agency of ordinary individuals; this would allow for deeper and more nuanced macro-historical representations. Moreover, such a combination can support efforts to teach students to break through 'philosophical thinking' and achieve 'ironic thinking' (Egan 1997). According to the Canadian educationalist Kieran Egan, 16- to 18-year-old learners are 'philosophical 
thinkers': They focus on and are especially interested in 'the real truth' as a coherent system that can explain the world and reality in its entirety (1997, 104-136). Attractive systems are, for instance, religion or Marxism, which describe the world through a coherent yet strict logic but risk turning young people into rigid and authoritarian thinkers. 'Ironic thinking', Egan continues, can precisely remedy this by showing that there are always exceptions and nuance, by pointing to the unique instead of the general and by revealing the complexity of historical events and developments that cannot be understood through one simple frame $(1997,137-171)$. Such ironic thinking, which also includes self-conscious reflection about language use in history, contributes not only to better historical understanding but also to civic engagement and identity building. It differentiates between structures, shatters homogenisation and highlights the importance of individual and collective action on the part of ordinary people.

\section{Bibliography}

\section{List of Textbooks Cited}

Bekers, K., K. Dillen, B. Hendrickx, R. Lindemans, K. Merckx, W. Moreau, J. Philips, L. Van den Broeck, J. Van Dooren and G. Goris. 2009. Storia 6. Wommelgem: Van In.

De Deygere, R., W. Dupon, K. Moermans, W. Smits, C. Van der Meeren,

S. Van de Perre, J. Vankeersblick and H. Van de Voorde, eds. 2009. Historia 6. Kapellen: Pelckmans.

Draye, G., G. Brock, H. Cools, K. Wils, eds. 2010. Passages. Na de Tweede Wereldoorlog. Averbode: Averbode.

Smeulders, M., I. De Leus, E. Steenackers, S. De Bock, M. Deserrano, W. Van

Der Spiegel, R. Paeps, B. Reusens, eds. 2014. Pionier 6. Berchem: De Boeck.

\section{Further References}

Alcoff, L. 1994. 'Cultural Feminism versus Post-structuralism: The Identity Crisis in Feminist Theory'. In Culture/Power/History: A Reader in Contemporary Social Theory, ed. by N.B. Dirks, G.H. Eley and S.B. Ortner, 96-122. Princeton: Princeton University Press. 
Barton, K. C. 2012. 'Agency, Choice and Historical Action: How History Teaching Can Help Students Think about Democratic Decision Making'. Citizenship Teaching and Learning 7, no. 2: 131-42.

Braudel, F. 1949. La Méditerranée et le monde méditerranéen à l'époque de Philippe II, 3 volumes. Paris: Armand Colin.

Brubaker, R. 2004. Ethnicity without Groups. Cambridge, MA: Harvard University Press.

Carlyle, T. 2010. On Heroes, Hero-Worship and the Heroic in History. New York: Cosimo Inc.

Clark, J. S. 2013. 'Encounters with Historical Agency: The Value of Nonfiction Graphic Novels in the Classroom'. The History Teacher 46, no. 4: 489-508.

Clark, J. S. 2014. 'Teaching Historical Agency: Explicitly Connecting Past and Present with Graphic Novels'. Social Studies Research and Practice 9, no. 3: 66-80.

Clark, J. S., C. Weber and K. C. Barton. 2011. "African Americans Were Getting Fed Up": Choice and Inevitability in New Zealand Students' Ideas about Historical Agency'. Presentation at the annual meeting of the American Educational Research Association, New Orleans, Louisiana.

Egan, K. 1997. The Educated Mind. How Cognitive Tools Shape Our Understanding. Chicago: University Press.

Erdmann, E. and W. Hasberg, eds. 2011. Facing - Mapping - Bridging Diversity: Foundation of a European Discourse on History Education, 2 volumes. Schwalbach: Wochenschau Verlag.

Flemish Ministry of Education and Training. 2000a. 'Secundair onderwijs, derde graad ASO: uitgangspunten bij de vakgebonden eindtermen geschiedenis' [Secondary education, third stage of general education: basic principles of the history standards]. http://eindtermen.vlaanderen.be/secundair-onderwijs/derde-graad/aso/vakgebonden/geschiedenis/uitgangspunten.htm (last accessed 26 October 2016).

Flemish Ministry of Education and Training. 2000b. 'Secundair onderwijs, derde graad ASO: vakgebonden eindtermen geschiedenis' [Secondary education, third stage of general education: history standards]. http://eindtermen. vlaanderen.be/secundair-onderwijs/derde-graad/aso/vakgebonden/geschiedenis/eindtermen.htm (last accessed 26 October 2016).

Fontaine, A. 2006. La Guerre froide 1917-1991. In 2 volumes. Paris: Editions du Seuil.

Ford, T. E. and G. R. Tonander. 1998. 'The Role of Differentiation between Groups and Social Identity in Stereotype Formation'. Social Psychology Quarterly 61: 372-84. 
Harris, R. 2011. 'Citizenship and History. Uncomfortable Bedfellows'. Debates in History Teaching, edited by I. Davies, 186-196. New York: Routledge.

Peck, C., S. Poyntz and P. Seixas. 2011. "Agency” in Students' Narratives of Canadian History'. The Future of the Past: Why History Education Matters, edited by D. Shemilt and L. Perikleous, 253-280. Nicosia, Cyprus: Association for Historical Dialogue and Research.

Seixas, P. 2012. 'Historical Agency as a Problem for Researchers in History Education'. Antiteses 5, no. 10: 537-53.

Taylor, C. 1989. Sources of the Self: The Making of Modern Identity. Cambridge: Harvard University Press.

Van Nieuwenhuyse, K., Wils, K. 2015. 'Historical Narratives and National Identities: A Qualitative Study of Young Adults in Flanders'. Belgisch Tijdschrift voor Nieuwste Geschiedenis: Journal of Belgian History 45, no. 4: 40-72.

Vanden Berghe, Y. 2008. De Koude Oorlog. Een nieuwe geschiedenis (1917-1991). Leuven: Acco.

Vanhulle, B. 2005. 'Waar gaat de geschiedenis naartoe? Mogelijkheden tot een narratieve analyse van naoorlogse Vlaamse geschiedleerboeken'. Bijdragen tot de Eigentijdse Geschiedenis 15: 133-75.

Vanhulle, B. 2009. 'The Path of History: Narrative Analysis of History Textbooks - A Case Study of Belgian History Textbooks (1945-2004)'. History of Education 38, no. 2: 263-82.

Westad, O. A., ed. 2000. Reviewing the Cold War: Approaches, Interpretations, Theory. Cold War Histories Series, volume 1. New York: Routledge.

Wils, K. 2009. 'The Evaporated Canon and the Overvalued Source: History Education in Belgium: An Historical Perspective'. In National History Standards: The Problem of the Canon and the Future of Teaching History, ed. by L. Symcox and A. Wilschut. International Review of History Education 5, 15-31. Charlotte, NC: IAP.

Wilschut, A. 2012. Burgerschapsvorming en de maatschappijvakken. AmsterdamAlkmaar: Landelijk Expertisecentrum Mensen Maatschappijvakken.

Wilschut, A., Van Straaten, D., Van Riessen. 2013. Geschiedenisdidactiek. Handboek voor de vakdocent. Bussum: Coutinho.

Zahra, T. 2010. 'Imagined Noncommunities: National Indifference as a Category of Analysis'. Slavic Review 69, no. 1: 93-119. 
Open Access This chapter is licensed under the terms of the Creative Commons Attribution 4.0 International License (http://creativecommons.org/licenses/ by/4.0/), which permits use, sharing, adaptation, distribution and reproduction in any medium or format, as long as you give appropriate credit to the original author(s) and the source, provide a link to the Creative Commons licence and indicate if changes were made.

The images or other third party material in this chapter are included in the chapter's Creative Commons licence, unless indicated otherwise in a credit line to the material. If material is not included in the chapter's Creative Commons licence and your intended use is not permitted by statutory regulation or exceeds the permitted use, you will need to obtain permission directly from the copyright holder.

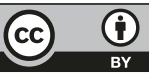

